\title{
Cambios en la vestimenta indígena en el altiplano andino bajo el colonialismo español
}

\section{Indigenous clothing changes in the Andean highlands under Spanish colonialism}

\author{
Christine D. Beaule ${ }^{1}$
}

\begin{abstract}
This article outlines a material culture approach that combines theoretical perspectives on exchange in value and the gendered body politic. This theoretical framework is applied to three elements of costume changes in the Spanish Colonial period (ca. AD 1532-1826) of Andean South America. I explore the impact of Spanish public policies, gender roles, and social ideals on the maskaypacha forehead fringe, inca male tunics (unku), and female shawls (lliqlla). I argue that changes in indigenous dress are largely confined to males in the Early Colonial period, which mirrors the gendered nature of the Spanish body politic. This material culture reading of indigenous clothing changes provides a useful model for analyzing the gendered categories of indigenous political symbols and costumes.

Keywords: Colonial period, indigeneity, gendered state, clothing, Andes.

\section{Resumen}

Se realiza una aproximación a la cultura material que combina perspectivas teóricas de intercambio de valor y el cuerpo político basado en el género. Se aplica este marco teórico a tres elementos de los cambios de la vestimenta en el período Colonial en los Andes (ca. 1532-1826 DC). Se explora el impacto de las políticas públicas españolas, el rol de los géneros y los conceptos sociales acerca de prendas inca como la masqkaypacha, las túnicas masculinas (unku) y el manto femenino (lliqlla). Se argumenta que los cambios en el vestuario indígena se limitan principalmente a los hombres del período Colonial Temprano, el cual es un reflejo de la naturaleza del cuerpo político espańol basado en el género. Esta lectura de los cambios en la cultura material de la vestimenta indígena provee un modelo práctico para analizar las categorías de género de los símbolos políticos indígenas y su vestuario.
\end{abstract}

Palabras claves: período colonial, indigenismo, género, vestimenta, Andes.

Recibido: 25 mayo 2016. Aceptado: 24 octubre 2017

1 Department of Languages and Literatures of Europe and the Americas, 462 Moore Hall, 1890 East-West Rd. University of Hawai'i at Mānoa, Honolulu, HI 96822, USA. Email: beaule@hawaii.edu 


\section{Introduction}

Much as we learn to read socio-economic status in the cut of a jacket or the brand emblazoned on a handbag, textiles have long been ways in which status, gender, marital availability, class, kinship, religious piety, political power and many other elements of identity are communicated. Textiles from the Spanish Colonial period (ca. AD 1532-1826) in the Andes offer us a valuable opportunity to contextualize changes in gender roles, ethnicity, religion, and other aspects of sociocultural organization in terms of early modern globalization. The specific material manifestations of Spanish conquest and evangelization efforts are an informative lens that we can use to document variability in ways that Spanish culture infiltrated indigenous ideologies. Although textiles from this period rarely preserve, there are a corpus of artifacts, housed in museums and private collections, and described in the published literature. These artifacts can be analyzed to read cross-cultural interaction in terms of stylistic influences, imposed cultural ideas about modesty, gender, and race, and the use of textiles to advertise and negotiate identity constructs. This article uses a small set of examples of $15^{\text {th }}$ to $18^{\text {th }}$ century clothing elements to document changes in Andean indigenous identities. I agree with Maynard that: "Because of the active interconnectedness of culture and economics, we need to stop thinking of traditional versus non-traditional clothing, and more about mediated social interaction and exchange systems" (2002, p. 191). The specific examples of inca textiles I analyze include male tunics (unku), female shawls (lliqlla), and elite forehead fringe (maskaypacha).

Using artifacts from museum collections and the published literature is challenging because so many of those objects are without specific context. The four textiles pictured in Figures 1 to 4, supplemented by descriptions of others published in books and articles, are not dated beyond the vague descriptor of "Colonial period". Nor are their original contexts described beyond the region (e.g., Andes) or country (e.g., Peru) known, thus limiting discussions about who might have once woven or worn these tunics. Secondly, the Colonial period in the Andes generally refers to the date range of Spanish political dominion, although the beginning and end dates of that occupation varied a great deal between and even within regions (and, in some cases, the Spanish never successfully established control over some communities or populations). I use 1532 as a starting date, marking the capture of Atahuallpa and the start of a 40-year battle that only ended in 1572 with the sacking of Vilcabamba and Tupac Amaru's execution (the last emperor of the neo-Inca State), but I recognize that the battle of Cajamarca marks the beginning of Spanish aggression rather than the establishment of Spanish political control. The imprecision of the Colonial period's starting year is compounded by our superficial understanding of exactly when intensive cross-cultural interaction between Spaniards, Africans and indigenous Amerindians took place in each region of the vast Andes. Thus a Colonial period tunic from Cusco may have been woven and worn as early as the mid $16^{\text {th }}$ century, or as late as the early 1800 s.

Coupled with details from others' scholarly work on indigenous clothing, colonial events and processes, and descriptions of textiles, these museum artifacts can be useful as illustrations that fit patterned changes in how indigenous individuals' clothing changed during the three centuries of Spanish colonialism in the Andes. The examples I use from this period come from Peru and Ecuador, but I argue that the patterns I describe are applicable to the larger region as well, at least in the cities and towns where cross-cultural interaction was more intense and frequent than in rural areas. The central claim here is that the changes in indigenous highland Andean tunics, shawls, and forehead fringe use reflect two related patterns: male clothing changes were more immediate and direct than their female counterparts because indigenous adult males interacted more directly and frequently with Spanish colonial administrators. Secondly, an exchange in value theoretical approach is applied to elite males' adoption of the scarlet forehead fringe in public performances, once the exclusive right of the Inca Emperor, as its rarity reflected their elite status, much like old ornaments and lace sleeves did for the wearers. Thus changes in the costumes worn by males, especially high status indigenous males, reflected new categories of status markers as well as the gendered (patriarchal) nature of Spanish colonial society. 
The theoretical approach employed in this article builds on Maynard's (2002) work through the construction of a material culture framework. The analysis of specific objects through a material culture framework helps me to identify and, more importantly, explain patterns of change and stability in indigenous men's and women's costumes. These patterns should be useful analogies for prehistoric changes in textile and clothing cuts and decoration. My research marries two related bodies of scholarship. The first is concerned with what I call exchange in value. An object that is imported over great distances, made of rare materials, whose possession is strictly controlled, or that is especially labor intensive is more valuable, as most archaeologists would agree. Examples of materials, styles and objects from a foreign culture that were adopted by indigenous peoples through global colonialism, especially by the elite class, abound. The exchange in value perspective helps to explain the adoption of the royal forehead fringe (maskaypacha) by $16^{\text {th }}$ century Andean indigenous elites, as well as elements of Andean highland women's dress today (e.g., German bowler hats, Filipino fringed shawls and Spanish skirts).

The second area of scholarship explores the gendered nature of the body politic (or the State as an imagined construct), specifically as it relates to indigeneity. The gendered character of political power is something that has been studied extensively in household archaeology, but much less so at the level of State or imperial politics. I aim to provoke or contribute to a larger discussion about the gendered nature of State politics in prehistory.

Finally, this article engages with a dynamic approach to identity in its inherent recognition of ethnicity as malleable. Within the Latin American political movements collectively known as indigenismo, political contestations about who is indigenous and what it means to be indigenous in various nations are tied up in battles about access to resources and political power, as well as changing gender roles and racial hierarchies. Clothing almost always advertises class, ethnicity, and marital status and so on, but it plays an especially pivotal role in indigenous political movements because costumes can signify identity and ethnic pride in ways that political banners do not. Thus it is not surprising to see young women donning indigenous highland Aymara and Quechua dress in Bolivia as statements of solidarity with the Kataristas (Canessa, 2000), an indigenous Aymara-centered political movement seeking to recreate the State as an indigenous nation, rather than a Western nation where they happen to be indigenous. Donning the pollera (a multi-layered skirt that is essential to and symbolic of Aymara identity in Bolivia) is thus as much about a vision of the State as it is about a women's identification as ethnically indigenous. But it is usually the women who express political affiliation in this manner, just as it is the women whose costumes have come to symbolize indigeneity itself in the Andes (Van Vleet, 2015).

In the indigenous political movements of Latin America today, it may be women whose clothing most clearly expresses shifts in identity politics within their nations, but the evidence presented here indicates that it was men whose clothing clearly expresses the gendered nature of colonial relationships between administrators, clergy, and indigenous communities. Thus the focus on the gendered nature of the body politic in the region, as expressed through indigenous clothing styles, reveals a more complex historical interplay between gender, colonialism, politics and indigeneity. This article focuses closely on the Colonial period in the Andes, but it has much larger implications for thinking about the role of material culture (such as clothing) in the social movements and gendered politics of prehistoric periods of great social and political change such as conquest, colonization, and similar contexts of intense cross-cultural interaction.

A material culture perspective also facilitates a close reading of changes in clothing styles as objects that reflect underlying processes of social and political change. As much as clothing sends messages about the wearer's wealth, status, gender identity, class, politics, religious membership and nationality, textiles themselves are social objects. Culture theorists have argued that the social life or biography of an object (see Appadurai, 1986; Craik, 1994; Kopytoff, 1986) refers to its function and purpose within its social context, and when that context is 
changing, the thing becomes an "object in motion" (Barrkman, 2006, p. 87). Textiles are social objects in motion that shape and are reinforced by identity politics, but so too are the indigenous identities they may represent.

This article is divided into two broad parts, the first providing both a theoretical and historical context for the changes described in the second half. It outlines an interdisciplinary theoretical framework that draws on fashion theory, anthropology/archaeology and history to build a material culture approach focused on exchange in value and gendered politics. This framework will be used to analyze the three costume changes that are the primary data: the maskaypacha forehead fringe, male unku tunics, and female lliqlla shawls. The objective is to use a close reading of these gendered clothing elements, the social objects in motion through time, to trace the roots of sociopolitical changes in the ways that indigenous identity was and is constructed in the Andes.

\section{Exchange in value}

The first of the two theoretical perspectives used here is exchange in value, which refers to the high value sometimes placed on objects or raw materials that are rare, imported or labor-intensive. In some cases, it is the textiles themselves that are exchanged; in other cases, textiles are domestically produced objects with forms, styles or motifs that reflect the exchange of ideas between cultural systems. Both of these categories illustrate cultural value added through cross-cultural interaction. Two ethnographic examples from non-Latin American indigenous contexts should suffice. In the first, the Atoin Meto people of West Timor use handwoven textiles as a traditional component of wealth and exchange during life cycle rituals, and as markers of clan identity (Barrkman, 2006, p. 86). Observers can identify someone's clan, region of origin and social status through textiles. In the Dawan language, garments are soea, or imbued with sacred power. Textiles imported from India have been incorporated into this sacred cultural tradition and are regarded as prestigious objects because of their rarity. Thus international trade networks connecting West Timor with the Middle East, India and China have influenced the relative value of sacred garments such as meo arm bands in the Atoin Meto culture. These are classified as sacred le'u objects, believed to provide the wearer with power and protection during warfare/ conflict, especially during headhunting, the most sacred ritual activity conducted by men (Barrkman, 2006, pp. 92, 98).

Cooksey's work (2011) on African raffia and bark cloth provides a second example of the influence of cross-cultural and interregional trade on the values of material goods. In some cultures, indigenous textiles "have endured as prestigious symbols of ethnic identity and socio-economic status," sometimes abandoned but later revived for the global market because of their aesthetically pleasing rich designs and colors (2011, p. 107). Examples include bark cloth (which uses bark from an equatorial species of fig tree) and raffia cloth (woven from the fibrous raffia palm, which grows in a wide band of West Africa). Raffia cloth is worn to demonstrate family wealth, because in the past, only commoners wore bark cloth (2011, p. 108). Typically woven on a loom by men and embroidered by women, raffia cloth has been worn during festivals in the royal capital to reinforce royal power, as well as Kuba (a historical kingdom in the Democratic Republic of the Congo) funerary rites where the deceased is dressed in raffia cloth so that her family and ethnic group members can recognize her. During the $17^{\text {th }}$ century, the Portuguese loved raffia cloth and imported it, while missionaries used it for liturgical vestments in $16^{\text {th }}$ century; it was later used as currency with Arab, Swahili and European traders.

In both of these examples, textiles were accorded higher status because they were imported, labor-intensive or came to symbolize membership in an ethnic group. Much like the higher status associated with luxury brand handbags and clothing today, elements of foreign materials or styles that are incorporated into indigenous traditional clothing, architecture and other material traditions may be held in higher esteem. The Andean examples of costume changes that are the main focus of this article fall into this category; however, it is the style and decorative motifs that reflect cross-cultural encounters, 
rather than the adoption of foreign textile materials as in the African examples above.

\section{Gendered bodies and the gendered body politic}

The second theoretical perspective that I rely on comes from a body of interdisciplinary scholarship loosely grounded in the politics of gender and power. Textiles that adorn furniture and walls make public statements about taste and status, but it is clothing that perhaps has the greatest potential for messaging and manipulation. Clothing can highlight or obscure the gendered characteristics of bodies, from men's broad shoulders and height to women's curves and breasts. But the body politic itself is also a gendered construction. Parkins (2002, p. 2) elegantly puts the two together when she writes about "how forms or items of dress -from the ceremonial to the everyday- can themselves becomes sites of political struggle, how they can be used variously to contest or legitimate the power of the state and the meanings of citizenship." Bodily display and performance may be politicized, but clothing is certainly not always contestatory. This version of the theoretical body politic puts the emphasis on "body," and distinguishes it from the concept of body politics associated with the State. However, the State itself -and its relations with specific groups inside or outside its borders- can also be thought of as gendered, in that household-State and community-State relationships may reflect gendered social ideals. For example, in the North American British colonies, patriarchal household authority stemmed directly from idealized relations between the British monarch and his subjects (Shammas, 1995). The nation-State is headed by a patriarchal figure whose responsibilities to his people are parallel to those between a father and his family. In this ideological sense, the State is gendered just like the household. This gender ideology is reflected in clothing as well, especially when State-household, and intra-household gendered relationships undergo radical change, as they did (to varying extents) in European colonies around the globe.

Though dress is not just about politics, it is always about specific bodies that have gender, sexuality, class and ethnicity. Kuchta (1996, p. 62) argues that the association of women's dress with political exclusion and fashionable adornment had implications for men's dress, so that after the $1688 \mathrm{Rev-}$ olution, French finery and excess, especially of the Court, gave way to much more modest dress among aristocratic men and plain dress among English men. This was due in part to a growing association between plain dress and public virtue in England. Thus larger social changes may be variably expressed in gendered fashions impacting men's but not women's dress, or vice versa.

Clothing is an important marker of social status, wealth, gender, marital status, religion and nationality; as such, and because of its malleability and personal nature, it is an especially rich area of material culture that we can use to explore changing categories of social identity in contexts of colonialism. Clothing is also, however, a tool that individuals can use to actively and publicly resist cultural change; one example of this function may be in men and women choosing to retain certain elements of indigenous patterns of dress, while others are replaced or revised over time. In the sections that follow, I focus attention on three different elements of indigenous dress that underwent big changes during the Colonial period in the Andes. These three examples reveal the gendered social contexts of colonialism in which Spaniards and indigenous peoples alike negotiated the shape and terms of a new colonial order.

\section{Inventing the indigenous other}

The social reorganization loosely directed by the Spanish during the three centuries that followed the Spanish wars of conquest impacted the construction of indigenous identity in two key ways. First, local cultural diversity, both within and outside of the inca Empire's vast territory, was to some extent subsumed in the process of creating indigenous groups for the purpose of more efficiently converting them to Catholicism and exploiting their labor. The Inca was still a quite young polity when Pizarro arrived on its borders in AD 1528; the Inca had yet to firmly establish political or economic control over much of the region. After the conquest of Vilcabamba in 1572, they faced the task of organizing a coherent 
polity from a huge, culturally diverse region and populations devastated by epidemic disease and warfare. In an effort to overcome the vast linguistic and cultural differences of the peoples, the Spanish chose a few indigenous languages in which they would teach communities the principles and rituals meant to essentially substitute for indigenous religious ideologies and theologies. Thus Spanish missionaries used Nahuatl (the language of the Aztecs, the most famous but far from the only polity at the time) in their evangelization efforts throughout the vastly diverse highland Mexican cultural landscape. Similarly, Andean highland groups were taught the Bible in Quechua, a language largely spoken by the small inca nobility in central Peru but not necessarily the millions under their loose political dominion (Jamieson, 2005, p. 217). The Spanish colonial system also imposed European modes of town planning, work schedules, writing and civil administration, and of course, the Catholic religion, on Andean indigenous peoples, with highly variable degrees of success.

The specific language choices made during the spiritual conquest of Mexico and the central Andes resulted in the formation of large language groups which are the basis for the largest and most populous indigenous ethnicities in the Andes today, the Aymara and Quechua. Similarly, the symbols (in cloth and otherwise) by which individuals declare, erase, or reinterpret their membership in those ethnicities are also subject to change over time. As Kleinert (2006, p. x; see also Hall, 1990) puts it, "identity is contingent and contested, entangled in the play of representations within and between social groups". Indigeneity provides an especially salient example of this.

In the post-conquest Andes, indigenous individuals could, within limits, change their identity within the racialized system of social organization imposed by the Spanish called the casta (caste) system. Jamieson (2005) lists several mechanisms by which people could manipulate or redefine their caste label. Court cases about inheritance that challenged individuals' legitimacy, migration between rural and urban communities, purchases of certificates of whiteness or legitimacy (cédulas de gracias al sacar) (Twinam, 2002), and marital alliances served as the basis for category changes. Moreover, "identity could be changed simply by a change of clothing or hairstyle, speech or attitudes" (Jamieson, 2005, pp. 228-229). These manipulations were, however, limited in their scope. As Voss (2008, p. 406) reminds us: "Clothing might at times transform poor people into gallant men, but it was also used to 'fix' social identities through sumptuary laws, commodity trade, and government regulations". The examples of clothing changes described in this article demonstrate that, clothing was one class of material culture used to project status in the new colonial social order, but the particular changes I describe did nothing to change the wearers' racial identity as indios.

Second, gender roles underwent tremendous changes during this Historical period. Colonial period indigenous gender roles in the Andean highlands ranged from Spanish patriarchy with its associated machismo, to female-headed households with strong businesswomen at the helm. The Spanish sought to replace indigenous forms of the family (e.g., multi-family households) with the nuclear, monogamous family founded on a Catholic marriage between one man and one woman, with the man squarely placed as the head of household and public representative of his family. These efforts too met with variable success; for most rural households, the infrequent contact with clergy and absence of Spanish administrators in their communities meant that these Spanish social ideals might be only nominally adopted. The Spanish emphasis on sheltered lives for women to ensure the family's honor was not attainable by most indigenous women due to the nature of their work (rare exceptions included indigenous elites and those living in Catholic convents as servants or low-ranking nuns) (Kellogg, 2005, p. 71).

The Spanish colonial administration conceived of men as the proper public representatives of their communities and families. Men, not women, conducted official business with the colonial government, fulfilled mita labor tax or tribute obligations, and engaged in long-distance trade and immigration networks. Because men's social and economic roles intersected with the colonial administration to a much greater extent than women's did, men's 
clothing reflected these radical shifts in social roles, while women's redefinition as men's legal inferiors resulted in their greater social isolation from public life.

Today, ethnographies show that men have greater access to wage labor and outmigration opportunities, which contributes to a more rigid division of household labor than is traditional in the Andes (Kellogg, 2005, p. 131). Women's relative isolation to the home community, coupled with their social role as the vanguards of their families' morality and honor under Spanish hetero-normative ideals, resulted in greater long-term adherence to traditional forms of dress. Nonetheless, women's clothing styles do reflect various influences from the intensive cross-cultural interaction that has characterized both the Colonial (ca. AD 1532-1826) and Republican (independence or post-colonial) eras. An Aymara woman today may put on a hat that is German in origin, a shawl that can be traced back to the Philippines (the manton de Manila), and a multi-layered woolen Spanish skirt (pollera); these clothing pieces mark her ethnicity as much as her birthplace and her language.

\section{Andean costuming through time}

In order to fully understand changes in highland indigenous Andean clothing that emerged in the Colonial period, we must first briefly review what little is known about clothing in the pre-Hispanic era. Much of these details are gleaned from rare artistic representations of people dating to prehistoric periods, or artistic or textual descriptions from early in the Colonial era. Indigenous commoners generally continued to wear same thing under the Spanish, but elites often adopted European fabrics and motifs, and males especially wore hats, pants and capes. By the $18^{\text {th }}$ century, non-elite indigenous men in Quito were also wearing hats and loose calflength pants, and some wore ponchos on top (Meisch and Rowe, 1998, p. 44). Indigenous male clothing, however, underwent the most radical and rapid shift in the decades immediately following the Spanish conquest of Cusco in AD 1532.

In pre-inca Ecuador, artistic evidence suggests men wore a loincloth and women a wrapped skirt, prob- ably supplemented with a cloak or mantle. However, that was likely altered once the region came under the political dominion of the inca Empire, because "if the Incas did not consider newly conquered peoples sufficiently clothed, as apparently was the case in the northern highlands of Ecuador, they ordered people to wear something similar to Inca dress" (Meisch and Rowe, 1998, p. 44). Inca female dress included a large square of fabric (called 'aqsu or 'anaku) wrapped around the body and secured with one or more tupu (straight pins), with a belt (chumpi) around the waist, a shawl (lliqlla) around the shoulders (also secured with tupu) and a headband (wincha). Figure 1 provides an example of an inca woman's aqsu or anaku. Male dress was a knee-length tunic (called unku or kusma), a small breechcloth, and large rectangular cloak. Males and females alike wore leather sandals ('usut'a) on their feet. Although there must have been a wide variety of weaving techniques and cloth categories, given the high esteem with which cloth was held in the Andes, there were neither status nor gender differences in the tailoring of garments but only in the cloth quality and ornamentation (Murra, 1962, p. 711).

During the Colonial period in the central Andes, women continued to wear 'aqsu or 'anaku with tupu in some provinces, and Spanish layered skirts (pollera), with or without multiple layers of petticoats underneath, in others. Two important elements of women's clothing have survived the centuries -the pollera skirt and lliqlla shawl-although each reflects the cross-cultural influences of colonialism. The pollera skirt can be traced back to $18^{\text {th }}$ century South American colonies, when it was a garment of the upper classes. Today it is so iconic of indigenous Aymara and Quechua dress in the Andean highlands that to "dress indigenous" in any form is to be de pollera (wearing the multi-layered pollera skirt). A second, equally important though more expensive element of an Andean indigenous woman's dress is a colorful, long fringed shawl called a lliqlla in Quechua; today, some are woven with metallic threads that catch the light, and some have a lacy translucent quality to them, but none I have ever seen have embroidery or motifs that make indigenous or local referents. Instead, roses or flowers may be worked into the lacy patterns, but little else, and they can 
be said to more closely resemble the Spanish mantilla or fringed shawl. Tracing the shawl's origins is an interesting exercise in cross-cultural connections and sartorial influences. Pre-colonial indigenous women in the highlands wore lliqlla shawls, but these were solid, embroidered, and sometimes dyed fabrics woven on traditional looms from llama or alpaca wool. At first glance, the modern indigenous shawl seems to be an imported European substitution for the lliqlla. The technique of knotting warp fringes was used in Europe to finish the cut ends of loom woven fabrics (Meisch and Rowe, 1998, pp. 46-47), but it is most commonly found on Chinese square silk shawls imported to the Americas via the Manila Galleon from the Philippines. Known as mantones de Manila, embroidered with floral patterns and with 45-60 cm (18-24 inch) long knotted fringe on all edges, they were fashionable in Spain and their colonies in the late $18^{\text {th }}$ and early $19^{\text {th }}$ centuries (Robinson, 1987, pp. 68-69). Thus the lliqlla,

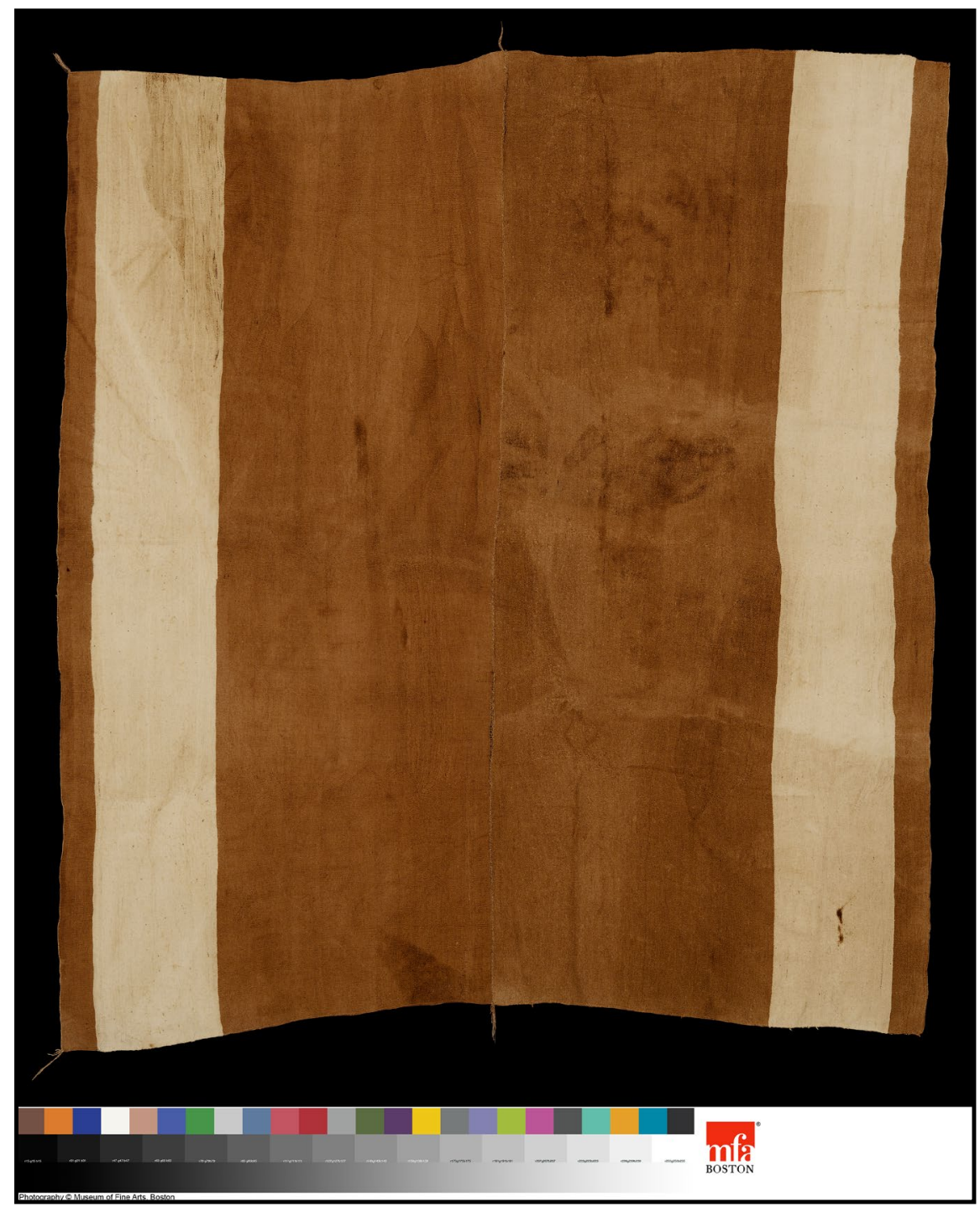

Figure 1. Inca 'aqsu or 'anaku (woman's dress); Peruvian, inca, before 1500. Cotton plain weave, Height $172.8 \mathrm{x}$ width 195.6 cm (68 1/16 x 77 in), without including the tails. Museum of Fine Arts, Boston, gift of David and Marita Paly, 2007.1157. Photograph (C) 2018 Museum of Fine Arts, Boston. 
a key component of a highland indigenous woman's dress, in fact comes from Chinese artisans in the Philippines, on the Manila Galleon to Mexico, continuing onto Spain, where elite fashions found their way back to the Andes via the transatlantic trade.

Women's costumes changed relatively little during the Early Colonial period for two key reasons. The first is because under the imported Spanish gender ideology, women were to be largely confined to their homes and local communities. Their fathers and husbands served as the public representatives of their families and communities and the points of articulation with the Spanish administration. The second reason is because indigenous highland women's costumes were perhaps less offensive to the Spanish; indeed, the Spanish seemed to have only taken issue with indigenous men's breechcloths. How women dressed was of relatively little concern. That said indigenous women in the Andean highlands today from Ecuador to Bolivia do wear one or more versions of a costume that reflects centuries of globalization and cross-cultural contact and trade. But imported elements of clothing such as chandelier earrings and fringed shawls shimmering with metallic threads were absorbed into a costume that continued its strong affiliation with indigenous women and came to signify their indigeneity.

Indigenous men are far more likely these days to wear cheaply produced cotton or rayon versions of Western middle-class businessmen's dress pants, leather loafers and button-down shirts, topped by cotton sweaters or jackets. During the Colonial period, some men's costume was a simpler version of an inca male's tunic, which continued to be worn until recently in some more remote parts of Bolivia and Ecuador. The rest of Ecuadorian men's costume is of Spanish colonial origin (Meisch and Rowe, 1998, p. 48); this included handmade shirts and pants worn until fairly recently, but machine-manufactured shirts are now nearly universal. Instead, it is the man's poncho or ruana that today signifies indigenous ethnicity; this item takes the place of the mantle, but not the tunic underneath, once woven by men on a backstrap loom and women on a foot loom (1988: 49). The earliest evidence for the production and use of ruana is among the Chilean Mapuche in the early $17^{\text {th }}$ century (Möntell, 1929, p. 239), especially when they started their 350-year long fight against colonization, mostly on horseback. The ruana spread gradually northward during the 1700 s, and by the early $19^{\text {th }}$ century, was generally worn throughout the Andes by men on horseback (and even by the mid $19^{\text {th }}$ century by upper-class women on horseback). Once again we see that a prominent symbol of indigeneity in Ecuador, the male poncho, traces its origins to early cross-cultural encounters, in this case, between an indigenous group at the opposite end of the Andes in Chile and the Spanish from whom they adopted the horse and modified a garment to facilitate horseback riding. Looking further back in time, the ruana was a replacement for the earlier inca tunic (unku). In the sections that follow, I describe two selected elements of the male indigenous costume that changed significantly as a direct result of Spanish colonialism.

\section{Maskay pacha forebead fringe}

The first example of clothing that changed significantly during the Colonial period was the scarlet forehead fringe called maskaypacha: a unique marker of ultimate political authority that came to mean something quite different for the post-conquest inca nobility in Cusco, Peru. Dean (1999, p. 123) argues that colonial inca elites used their bodies as "empowered sites of cultural confluence" to reinforce their superior status within the new sociopolitical hierarchy. In public performances such as the Corpus Christi festivals of Cusco, the caciques principales (nobles) wore a modified inca costume that functioned as a symbol of office because of their aesthetic associations with the Sapa Inka ("unique Inka" or emperor). In the version of inca history that was refashioned after the conquest, there were 24 caciques recognized by the surviving nobility, with two chosen from each line that purported to descend from one of the 12 pre-Hispanic inca rulers. At least one of the 12 rulers was almost certainly mythical, ${ }^{2}$ but this group of 24 individuals was chosen and titled alférez real (standard bearer). Their identification as standard bearers was marked by wearing the scarlet forehead fringe known as

2 See Covey (2006) for debates about inca dynastic history. 
maskaypacha; this is fascinating because the scarlet maskaypacha was the sole privilege of the Sapa Inka (emperor) before the conquest.

Within less than a century, the forehead fringe's signification changed even more; it came to simply denote elite status, distinguishing the wearer from both Spaniards and non-inca Andeans (Dean, 1999, p. 102). In the process, the maskaypacha lost not only its religious connotations but also its meaning as symbol of ultimate political authority (1999: 110). Thus the re-signification of this all-important symbol of inca authority became, instead, a marker of ethnic identity and social class restricted to inca elite males who held positions of authority in local parishes (1999, p. 131). By the $18^{\text {th }}$ century "indigenous Andeans enjoyed relative freedom to reconstruct and reenact inca history through literature, performance, and the visual arts" (Cohen Suárez, 2015, p. 134). The maskaypacha's appearance in public performances of elite indigenous status makes it an example of a costume element that took on a very different meaning even though it kept its pre-colonial form.

The spread of the emperor's scarlet forehead fringe to the elite leaders of parishes was accompanied by the incorporation of foreign symbols of rulership as well. Mid Colonial (17 $7^{\text {th }}$ century) portraits of both inca nustas (princesses) and Corpus Christi impersonators of inca kings (the alfereces reales) also show a greatly modified headdress that became part of the inca nobles' ethnic costume. These headdresses more closely resembled European monarchs' crowns than their precolonial antecedents, but the common inclusion of clearly foreign motifs at the center of the headdresses is striking. Castles with flying pennants, Hapsburg eagles and shields figure prominently (Dean, 1999, pp. 131-141). These crown-like headdresses became, like the re-signified maskaypacha, symbols of elite status and political authority.

\section{Male tunics (unku) and female shawls (lliqlla)}

Inca elites retained pre-Hispanic forms of dress in some circumstances well into the Colonial period.
Male nobles and royalty collectively referred to as caciques wore tunics (called unku) of cumbi. Early colonial chroniclers indicate that high-status $u n k u$ were woven from cumbi, a double-face tapestry-weave cloth made with llama, alpaca and vicuna wool and whose pre-Hispanic use was restricted to nobility (Cobo, 1990 [1653], as cited in Pillsbury, 2006; Dean, 1999, p. 124); its production was restricted by the Inca, as were the number of camelids anyone could own (Pizarro, 1944 [1571], p. 83, as cited in Pillsbury, 2006, p. 126). Cumbi retained its high-status connotations into the colonial era, but its use was extended to anyone who could afford it. It was equally prized by Europeans, some of whom compared it to silk and had it made into wall hangings, bedspreads and other artefacts where fine textiles were customarily used by Colonial period European elites.

The form of the unku continued, however, though it was sometimes shortened for use over breeches (instead of a loincloth) or modified by the addition of lace sleeves. Although quite popular in Peru, Andean artisans did not often produce lace (Stanfield-Mazzi, 2015, pp. 79, 81). Demand for finely woven $u n k u$ continued even for occasions strongly discouraged by Spanish, such as giving mummies new garments each year (Pillsbury, 2006, p. 135). Even in the $18^{\text {th }}$ century, "'textiles of ancient design' were recorded on clandestine mummies that were being cared for by members of their lineage" (Salomon, 1987, p. 160). Inca-style tunics also featured prominently in festivals of the Virgin Mary, paintings of Corpus Christi festivals and religious art throughout the period; in some early $17^{\text {th }}$ century churches, wooden images of Christ were dressed like inca rulers (Dean, 1999, p. 252; Romero, 1923, p. 449). Clearly, these hybrid uses of an indigenous garment reflect their widespread use as indicators of indigenous political authority and social status. The appearance of unku in Catholic contexts was not entirely uncontroversial, however. As late as 1781, Bishop Juan Manuel of Cusco complained about the use of inca dress in religious festivals and miniature tunics on Christ images (Pillsbury, 2006, p. 137). But for the most part, continued use of unku was treated with indifference by colonial authorities and was less threatening to the social order than 
continued worship of huacas (sacred places and objects on the landscape).

In cumbi unku worn by Andean indigenous elites during the Colonial period, on the other hand, both the formal syntax (spatial arrangement of decorative motifs) and the motifs themselves underwent sometimes radical changes. Iriarte (1993) studied tunics depicted in colonial paintings, and found that post-conquest unku are generally more elaborately decorated than their pre-colonial counterparts. Tunics in Colonial period painting more often have decorations on the entire body of the garment, rather than confined to thin bands along the neck, waist and borders as pre-Hispanic exemplars show. Moreover, decorative motifs changed from largely geometric ones (see Figures 3 and 4) to include insects, butterflies, quatrefoils and flowers. The $18^{\text {th }}$ century Peruvian lliqlla depicted in Figure 2 provides an example of this.
Dean (1999, p. 125) suggests that these changes in the decoration of unku were influenced by European brocade, and that they emphasized the nobility of the wearer. Indeed, it was quite common early in the Colonial period for indigenous elites to claim direct genealogical links to inca royalty (and many Spanish soldiers who participated in the conquest married inca "princesses"). These unku were often further elaborated by the addition of flowing lace sleeves, though Dean stresses that the lace was neither tailored nor finished in a European manner. Instead, lace sleeves are uncuffed and free flowing, and so "should be understood as a product of the traditional Andean appreciation of fine fabric" (1999, p. 125). The addition of lace to cumbi as an element of fine cloth demonstrates exchange in value. The costume was Hispanized, however, by the addition of breeches underneath that end at the knee, and with a fringed band of cloth (called a saccsa or antar) encircling the leg at the knee (a pre-Hispanic inca

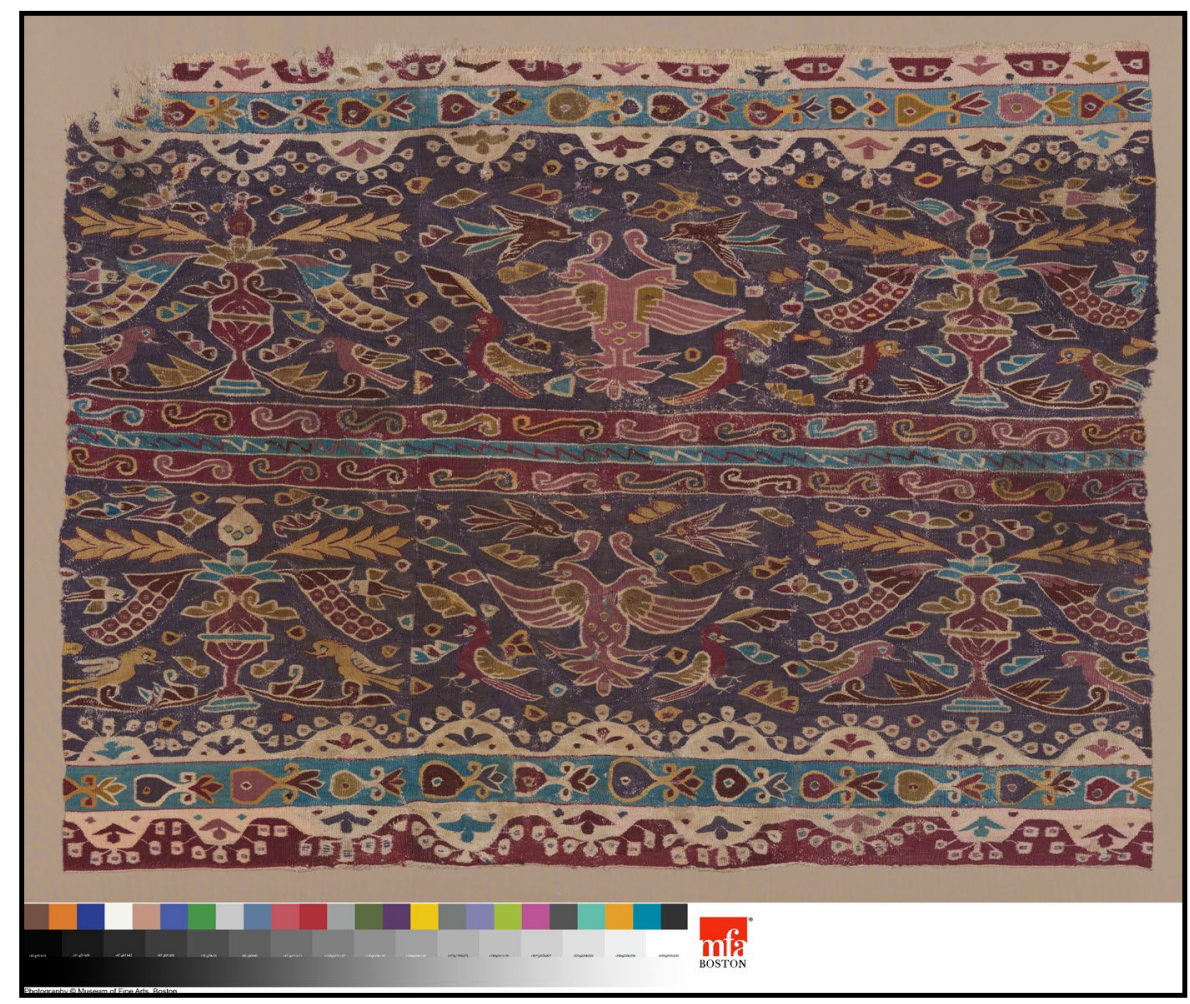

Figure 2. Peruvian indigenous lliqlla (women's mantle), tapestry with cotton warps and wool wefts, and European colors and designs; Peruvian, probably inca, $18^{\text {th }}$ century, Length $88.9 \mathrm{~cm}$ x width $114.3 \mathrm{~cm}$ (35 x 45 in). Museum of Fine Arts, Boston, gift of David and Marita Paly, 2015.2127. Photograph (C) 2018 Museum of Fine Arts, Boston. 
accessory). Breeches were worn because the pre-Hispanic costume of unku over a wara (loincloth) was seen as inappropriate by the Spanish (Cummins, 1991); to facilitate the movement of the tunic over the breeches, Colonial period tunics were either made shorter or slit up the sides (Pillsbury, 2006, pp. 133-134). The overall effect of pairing a shortened tunic over breeches was to turn the unku into a Spanish camiseta (a long, loose-fitting shirt) (Dean, 1999, p. 126).

This second example of changes in indigenous costumes reflects indigenous resistance to the imposition of Spanish cultural ideals. New socio-political opportunities for advancement within the casta system created social mobility in indigenous communities, and indigenous elites sometimes expressed their higher status through the selective use of imported elements: lace sleeves, feather or Spondylus shell collars (sipe and mullu) and large gold or silver badges with sun motifs (veneras or capinos). These foreign elements would have been rare in wearers' indigenous home communities, thus increasing their value as status markers. The foreign referents encompassed by these changes -sleeves, collars and badges- to male, not female, costumes also reflect the gendered intersection of the Spanish and indigenous worlds in the mid $16^{\text {th }}$ to early $19^{\text {th }}$ centuries. As their families' and communities' representatives, (socially elite) men had access to foreign fashions that women were denied. The emerging body politic in the colonial Andes was clearly gendered male.

In contrast to $u n k u$, women's shawls are relatively rare finds in the Andean archaeological record. There are a few key examples however that illustrate the incorporation of foreign motifs like their male counterparts. One $18^{\text {th }}$ century example is depicted in Figure 2, a lliqlla from the Museum of Fine Arts in Boston. The decoration on this cloth is divided into two zones, each composed of European colors and iconography such as birds, urns, and flowers in vases. This rare example of a lliqlla is especially notable for its European influences, particularly when contrasted with the female 'anaku (dress) in Figure 1. For indigenous women in colonial institutions such as convents, the lliqlla would have been an unusual garment, let alone one with such obvious foreign referents. This garment was likely commissioned or woven, and worn by an elite indigenous woman who like elites, throughout prehistory, communicate status via rare or labor-intensive possessions, made of highly valued material or with visible referents to prestigious foreign cultural contexts. An unku or lliqlla with royal European purple dyes, flowers and hummingbirds, a royal lion or crest, were the Colonial period equivalent of imported fine pottery and gold artifacts depicting an empire's gods or king in a conquered elite's tomb. These artifacts, however rarely produced or preserved, reflect changing ideas about the symbols of elite status and political power, but they would have functioned exactly the same as imported luxury goods did in pre-Hispanic archaeological contexts such as elite households, temples, and tombs.

Many mid $16^{\text {th }}$ to $17^{\text {th }}$ century illustrations and paintings from the Andes show inca nobility and soldiers alike wearing unku covered with various versions of a checkerboard motif (see Figures 3 and 4). The black and white checkerboard motif was one of the most common designs, with inverted stepped red triangles around the neck (Pillsbury, 2006, pp. 128-129); in fact, Francisco de Xerez (1985 ([1534], p. 110) describes "the arrival of Atahualpa's army in Cajamarca, with men dressed in livery like a chessboard." The black and white checkerboard motif on textiles is commonly accepted as representing terraced mountainsides and agricultural fields, which were part of Kay Pacha (earthly realm of ploughed fields, stepped terraces, towns and cities), as opposed to Hanan Pacha (the celestial world) and Urku Pacha (the underworld) (Hogue, 2006, p. 102). Milton et al. (1986, p. 82) note that Pedro Sánchez de la Hoz, one of the few Europeans to see inca Cusco before its destruction, wrote: "There are many houses of adobe and they are well laid out; the streets are in a checkerboard pattern and very narrow, all paved and with water channels running down the middle".

Thus the organization of space in the urban cityscape as well as the rural landscape were idealized and reflected in textile motifs. Hogue (2006, pp. 108-109) interprets the common stepped motif found carved into rock at many inca heartland 


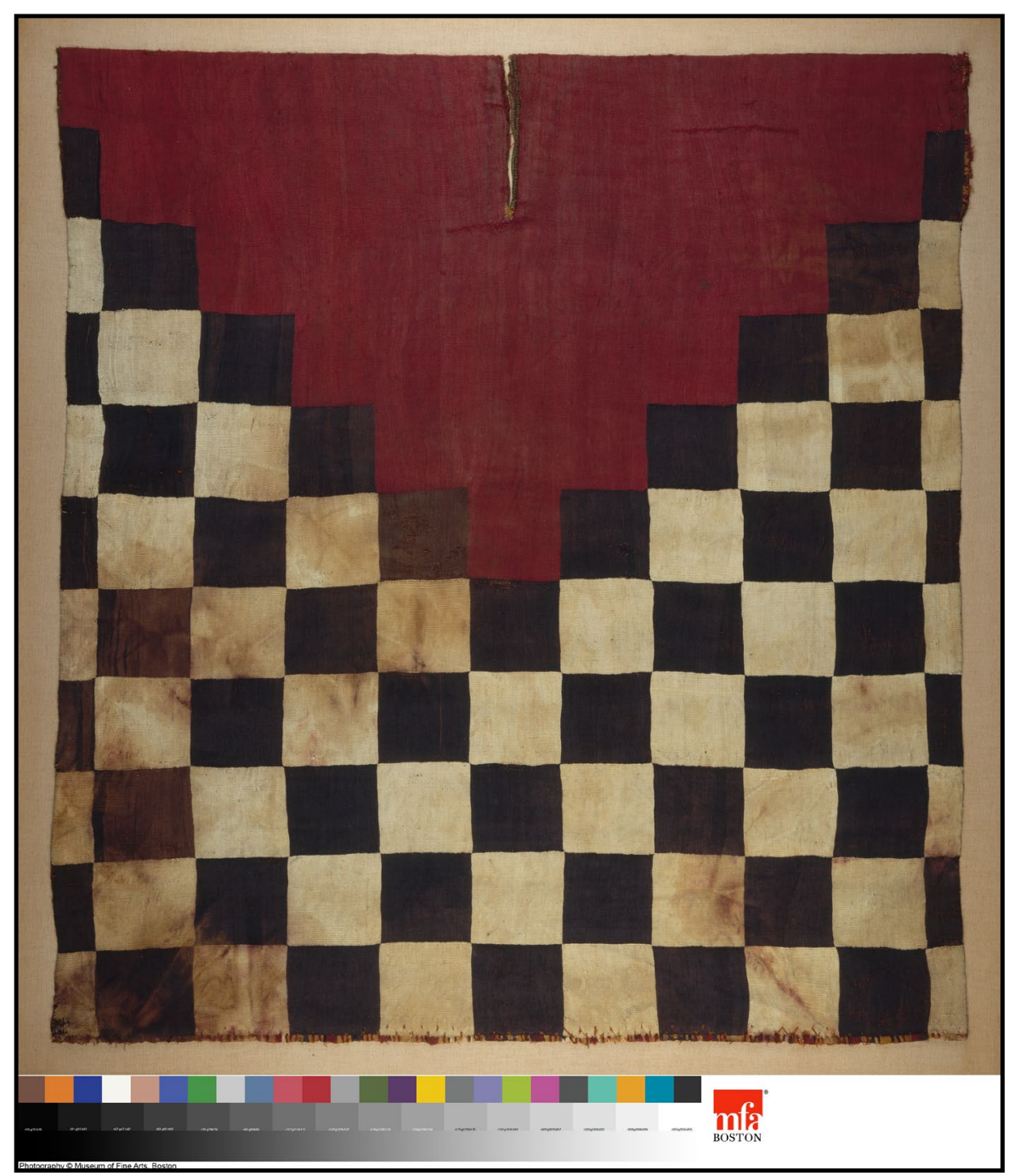

Figure 3. Late Horizon period (AD 1476-1534) Inca unku (tunic) with checkerboard motif; wool interlocked tapestry; cross-knit lop-stitch embroidery over hem; figure-8-stitch embroidery over side seams; running stitch embroidery above hem. Length 84.5 x width 78 cm (33 1/4 x 30 11/16 in). Museum of Fine Arts, Boston, William Francis Warden Fund, 47.1097. Photograph (C) 2018 Museum of Fine Arts, Boston.

sites such as Sacsahuaman fort (the carved stepped platform of throne of the Inca $u s h n u^{3}$ ), in the Royal Mausoleum at Machu Picchu, and the Bath of the Nusta at Ollantaytambo as representing the element of water, with its implications of fluidity of movement and sound. The most common geographic motifs in inca textiles include the step, zigzag (qenqo in Quechua) and rectangle -when used together, they have the collective appearance of a serpent, and

3 An ushnu is a pyramid-shaped, terraced structure that was used by the incas to preside at the most important ceremonies of the Tawantinsuyu. the serpentine line is an ancient symbol of water and other sacred fluids in this region. ${ }^{4}$

Some unku, usually those associated with the standard bearers or other high nobles, had bands of decorative motifs called tocapu crosscutting the body of tunics into two or three zones. Tocapu are "rectangular compositions of nonrepresentational, geometric forms [...] aligned end to end and stacked to form

4 See Figure 8 in Hogue (2006) for a Late Horizon period example. 


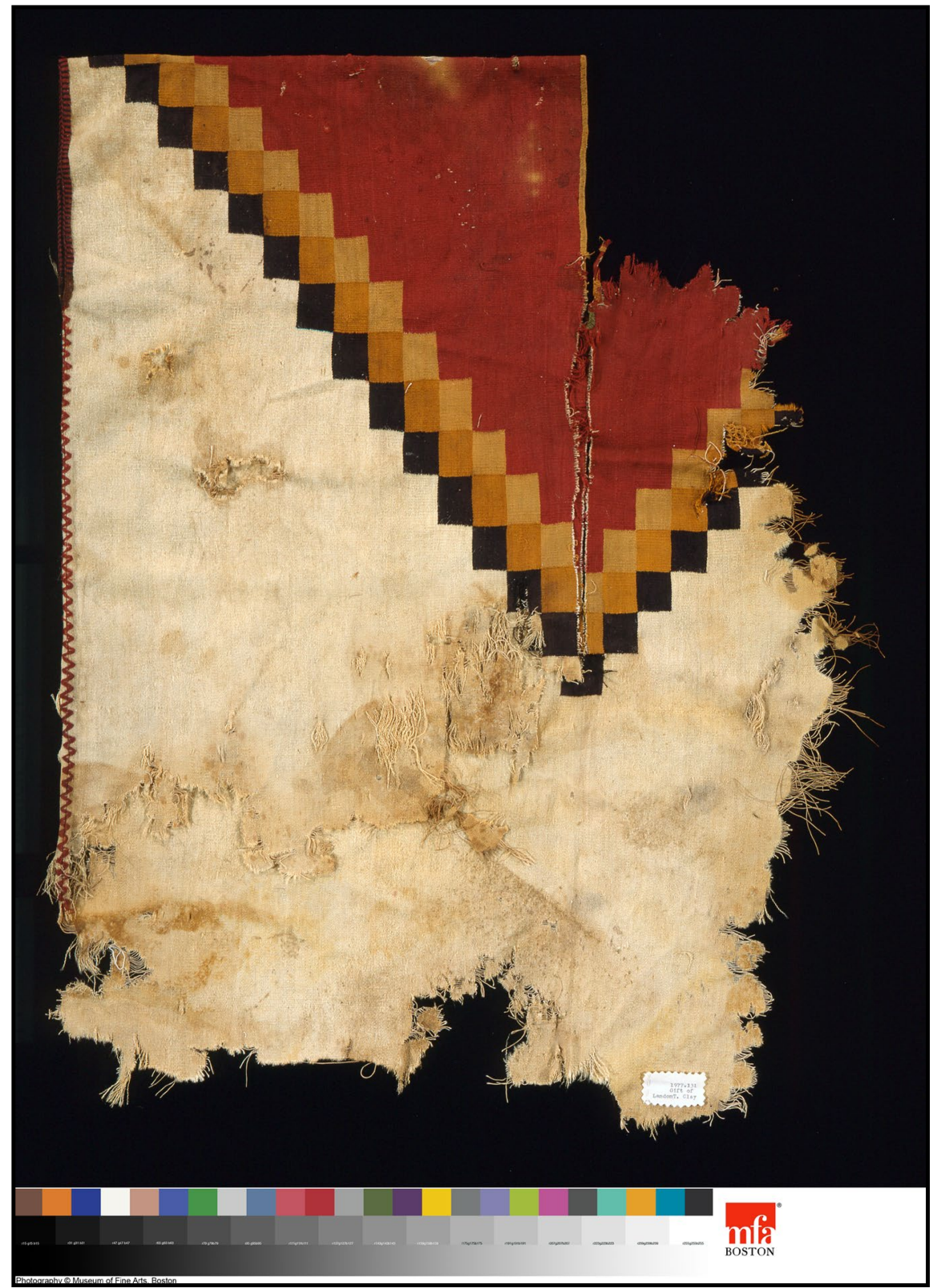

Figure 4. Fragment of a Peruvian Late Horizon/Early Colonial period (ca. AD 1500-1550) Inca unku (tunic) with decorative border; cotton and wool interlocked tapestry. Length $76.2 \mathrm{~cm}$ x width $60.9 \mathrm{~cm}$ (30 x $24 \mathrm{in})$. Museum of Fine Arts, Boston, gift of Landon T. Clay, 1977.131. Photograph (C) 2018 Museum of Fine Arts, Boston.

a grid of repeating motifs" (Dean 1999, p. 123). In contrast to checkerboard unku, unku with tocapu motifs were scarce; Cieza de León (1959 [1551], Chapter 6, p. 31, as cited in Pillsbury, 2006, pp. 128-29) referred to them in the mid $16^{\text {th }}$ century as "king's robes," and Guamán Poma included tocapu in his illustration of the Inka royal family's garments (1980 [1615], pp. 106, 110, 377, 440, 442, 449, as cited in Pillsbury, 2006, pp. 128-29). Their ordered appearance on an unku, Dean argues (1999, p. 111), served as "woven signifiers of the vastness of the inca empire," and the diversity of tocapu within a garment demonstrated the diversity of peoples he ruled. This interpretation is 
bolstered when contrasted with the relatively plain tunics worn by lesser-status inca, usually limited to a standardized single motif like the stepped red, white and black checkerboard (1999, p. 113) in Figures 3 and 4. Cummins (2011, p. 300, 305) cautions us, however, against interpreting tocapu as a "fixed set of signs", arguing convincingly that they are polysemic.

Pillsbury writes (2006, p. 127) that "pre-Hispanic uncu, as a group, share remarkably conventional designs, due in part to the restrictions placed on their creation". The number of motifs was usually restricted to two or three, with the waist, neck and lower border reserved for special decorative attention. Large areas of unku were left unadorned, much like the bands of decoration on ceremonial drinking vessels called qeros or kerus. The unku in Figures 3 and 4 provides a good example of this qero-like pattern. Motifs were again largely confined to highly abstract imagery, and generally avoided animal or human figures; decorations used few colors, including red, yellow, brown and black, while green, white, blue and purple were rare (2006, p. 127). But even these conservative garments were subject to modification. As mentioned earlier, some unku designs began to include flowers, insects and other European elements, while others sported untailored lace sleeves. Perhaps, though the most remarkable examples come from the isolated town of the last inca kings, Titu Cusi Yupanqui and his brother Tupac Amaru, who ruled a neo-inca State from their secret mountain retreat of Vilcabamba for several decades after the Spanish conquest of Cusco. The two brother kings were discovered in 1569 wearing unku, but Titu Cusi Yupanqui's was made of blue damask while Tupac Amaru's was crimson velvet (Cúneo Vidal, 1925, pp. 228, 292, as cited in Pillsbury, 2006, p. 131). Given that Vilcabamba was a secret mountain retreat from which these two rulers continued to foment rebellion after the fall of Cusco, it is remarkable indeed that their royal garments were constructed from Spanish luxury fabrics instead of fine camelid wool. But in fact these unku typify the early colonial impact on indigenous males' textiles, with major changes in the adoption of certain European luxury fabrics or Spanish elite imagery into otherwise conventional inca designs.
Colonial garments were mainly made with sheep's wool, had much lower thread counts, and some use of silk and metal-wrapped yarns in addition to camelid wool. But they were usually produced using much the same techniques as in pre-Hispanic times. Pillsbury (2006, pp. 138-39) writes that the biggest shift was in designs; with the restrictions on the use of cumbi and certain motifs and colors gone, the cumbi camayoc (specialized cum$b i$ weaver) could weave tapestries on commission and to the design specifications of the customer (Rowe, 1978, p. 6). Andean nobility who were not allowed to do so beforehand quickly took advantage of new opportunities to order previously restricted designs on their unku. And "accounts of the Colonial period are filled with stories of individuals claiming descent from inca emperors in order to improve their situation" (Rowe 1954, as cited in Pillsbury 2006: 139). Guamán Poma (1980 [1615], p. 800) even complained with disgust that a humble Andean steward could wear the tunic of a lord.

I agree with Pillsbury (2006, p. 139) that the incorporation of new design elements could only happen within an Andean logic. By retaining recognizable pre-Hispanic forms, tocapu, white tunics, and maskaypacha could be readily associated with the social and cultural traditions of the past. Thus new imagery was inserted into pre-existing structures rather than dramatic changes in design structure. For example, tocapu were previously an elite privilege, but were found nearly everywhere by the $18^{\text {th }}$ century, including yoke and side embroidery. They also sometimes included European heraldic animals such as kingly lions, and with European and Andean imagery scattered across the entire design field, as opposed to large areas without decoration in pre-Hispanic tunics (2006, p. 141). Two common pre-Hispanic types, the checkerboard unku and a type known as the "inca key", were closely associated in the past with the inca military (Cummins, 2002, pp. 93-95; Pillsbury, 2002, pp. 75-76), so it is not surprising that they largely disappeared under Spanish rule. Although tunics do not include urns, baskets and fruit, these became common motifs on textiles such as wall hangings during this era (Pillsbury, 2006, p. 145). 
The use of colors changed too, with much greater use of blue and red, and newly introduced pink and purple. In the pre-Hispanic era, the most highly prized fine camelid wool was white in color; white becomes a common background color during the Colonial period. Blue was also highly valued in the pre-Hispanic era and only associated with textiles of very high thread counts, but it becomes "positively profligate" during the Colonial period, possibly because it was the color most associated with royalty in Europe at the time.

Thus changes in Andean indigenous clothing can be read as a reflection of colonial forms of political subjugation, cross-cultural contact, the introduction of new materials and styles, and conflicting gender ideologies. The adoption of maskaypacha forehead fringe as a symbol of elite status, rather than the unique marker of an Emperor's political superiority as it once was, provides one good example of a change in social meaning rather than form. Inca unku, on the other hand, changed significantly in material, colors, and the diversity and spatial arrangement of decorative elements (including tocapu), although the basic tunic construction remained largely unaltered. The lliqlla in Figure 2 provides a good example. These examples from indigenous Andean costumes reflect some of the tumultuous sociopolitical and cultural changes that marked the Colonial period in the northern and central Andes.

\section{Final reflections}

If these few examples of textiles in museums are indicative of Colonial period changes in ethnicity, indigenous identity and gender roles, then I argue, the basic forms of indigenous costume changed in response to gendered Spanish norms, while the more radical shifts in iconographic referents, decorative syntax and motifs reflect the tumultuous nature of sociopolitical reorganization in the early colonial State. That these changes are largely confined to male indigenous costumes from the period mirrors the gendered nature of the Spanish body politic, which put the male head of household and community squarely in the public domain. The incorporation of foreign (Spanish) motifs and costume elements such as breeches and sleeves was eventually followed by similar changes in indigenous female costumes. As public figures, indigenous males' clothing was subject to Spanish influences to a much greater degree than what their wives and daughters wore.

But this does not explain why symbols of political authority or elite social status, such as lace sleeves and the Sapa Inca's scarlet forehead fringe, should be quickly adopted by non-royal nobility. Applying the exchange in value perspective, however, does explain those particular costume changes, by recognizing that foreign materials such as lace and velvet were valuable because of their rarity, just as the maskaypacha was rare (in fact, worn by just one person at a time) under the Inca. The transformation of clothing elements once highly restricted to royalty or to sociopolitical elites, into symbols of indigenous elite status, is the result of exchange in value. That these clothing changes were primarily seen in what males wore, rather than females, is explained by the male-centered nature of the Spanish colonial State. This combination of exchange in value and gendered body politics is a useful theoretical framework for examining changes in indigenous men's public appearances (their clothing) during the first century or two of Spanish colonialism in the Andean heartland of the Viceroyalty.

But in the modern Andean political context, it is the women whose indigenous clothing puts them squarely in the public eye -on postcards mass produced for tourists, and at folklore festivals and cultural performances (Schneider, 2007; Van Vleet, 2015; Weismantel, 2001). In Bolivia, the political and sociocultural revitalization of indigenismo movements under President Evo Morales and the Movimiento al Socialismo (MAS) political party, certain symbols of indigenous ethnicity (and, by extension, political power) have gained prominence. These include the coca leaf and Aymara wiphala flag; but indigenous politicians also celebrate a version of indigenous dress - namely the adult Aymara or Quechua woman's pollera (skirt), lliqlla (shawl) and bolero (hat) - as ethnic markers. That these particular elements of female indigenous costume have no pre-colonial antecedents is irrelevant. Fashion is quite capable of absorbing foreign elements in form and decoration, and of continuing to serve as 
symbols of ethnic identity and political affiliation, even (or perhaps especially) in times of social turmoil and intense cross-cultural interaction such as colonialism.

\section{Acknowledgements}

Parts of the text of this article were first published as "Andean clothing, gender and indigeneity in Colonial Period Latin America" in Critical Studies in Men's Fashion 2(1), 55-73 (2015). I would like to thank the editors and publisher of that journal for permission to reprint parts of that text. I would also like to thank Dr. Sara M.L. López Campeny and Dr. Carolina Agüero Piwonka for organizing the Tensioning Fibers Symposium at the $55^{\text {th }}$ Congreso Internacional de Americanistas in San Salvador, El Salvador. Finally, I thank the participants and attendees of that Symposium, and the three anonymous reviewers, for their useful feedback on earlier drafts of this argument.

\section{References}

Appadurai, A. (1986). The social life of things. Cambridge: Cambridge University Press.

Barrkman, J. (2006). Symbols of power and life: indian trade textiles and their inclusion into the ritual practices of headhunting and ceremonial houses by the Atoin Meto of West Timor. En Kleinert, S. (Ed.). Crossing cultures: art, politics, and identity (pp. viii-xiv). Darwin NT: Charles Darwin University Press.

Canessa, A. (2000). Contesting hybridity: evangelistas and kataristas in highland Bolivia. Journal of Latin American Studies, 32(1), 115-147.

Cieza de León, P. (1959) [1551]. The Incas. Von Hagen, V. W. (Ed.), De Onis, H. (Trad.). Norman: University of Oklahoma Press.

Cobo, B. (1990) [1653]. Inca religion and customs. Hamilton, R. (Ed. y Trad.). Austin: University of Texas Press.

Cohen Suárez, A. (2015). From the Jordan River to Lake Titicaca: paintings of the baptism of Christ in colonial Andean churches. The Americas: A Quarterly Review of Latin American History, 72(1), 103-140.
Cooksey, S. (2011). Bark and raffia cloth: interpreting indigenous prestige. En Cooksey, S. (Ed.). Africa interweave: textile diasporas (pp. 107-112). Gainesville: Samuel P. Harn Museum of Art, University of Florida.

Covey, R. A. (2006). Chronology, succession, and sovereignty: the politics of Inka historiography and its modern interpretation. Comparative Studies in Society and History, 48(1), 169-199.

Craik, J. (1994). The face of fashion: cultural studies in fashion. Nueva York: Routledge.

Cummins, T. B. (1991). We are the other: Peruvian portraits of Colonial Kurakakuna. En Andrien, K. y Adorno, R. (Eds.). Transatlantic empires: Europeans and Andeans in the sixteenth century (pp. 203-232). Berkeley: University of California Press.

Cummins, T. B. (2002). Toasts with the Inca: Andean abstraction and colonial images on quero vessels. Ann Arbor: University of Michigan Press.

Cummins, T. B. (2011). Tocapu: What is it, what does it do, and why is it not a knot? En Boone, E. H. y Urton, G. (Eds.). Their way of writing: Scripts, signs, and pictographies in pre-Columbian America (pp. 277-317). Washington, D. C.: Dumbarton Oaks.

Cúneo Vidal, R. (1925). Historia de las guerras de los últimos incas Peruanos contra el poder Español. Barcelona: Casa Editorial Maucci.

Dean, C. (1999). Inka bodies and the body of Christ: Corpus Christi in colonial Cuzco, Peru. Durham: Duke University Press.

De Xerez, F. 1985 [1534]. Verdadera relación de la conquista del Perú. Bravo, C. (Ed.). Crónicas de América 14. Historia 16 , Madrid.

Guamán Poma de Ayala, F. (1980) [1615]. El primer nueva corónica y buen gobierno. Murra, J. y Adorno, R. (Eds.), Urioste, J. L. (Trad.). Ciudad de México: Siglo Veintiuno.

Hall, S. (1990). Cultural identity and diaspora. En Rutherford, J. (Ed.). Identity: community, culture and difference (pp. 222-237). Londres: Lawrence and Wishart.

Hogue, M. (2006). Cosmology in Inca tunics and tectonics. En Young-Sanchez, M. y Simpson, F. W. (Eds.). 
Andean textile traditions. Papers from the 2001 Mayer Center Symposium at the Denver Art Museum (pp. 100119). Denver: Denver Art Museum.

Iriarte, I. (1993). Las túnicas incas en la pintura colonial. En Urbano, H. (Ed.). Mito y simbolismo en los Andes: la figura y la palabra (pp. 53-86). Cusco: Centro de Estudios Regionales Andinos Bartolomé de Las Casas.

Jamieson, R. W. (2005). Caste in Cuenca: Colonial identity in the seventeenth century Andes. En Casella, E. y Fowler, C. (Eds.). The archaeology of plural and changing identities: beyond identification (pp. 211-232). Nueva York: Kluwer Academic.

Kellog, S. (2005). Weaving the past: a history of Latin America's indigenous women from the pre-Hispanic Period to the present. Oxford: Oxford University Press.

Kleinert, S. (Ed.). (2006). Introduction. En Crossing cultures: art, politics, and identity (pp. viii-xiv). Darwin NT: Charles Darwin University Press.

Kopytoff, I. (1986). The cultural biography of things: commoditization as process. En Appadurai, A. (Ed.). The social life of things (pp. 64-91). Cambridge: Cambridge University Press.

Kuchta, D. (1996). The making of the self-made man: class, clothing, and English masculinity, 1688-1832. En De Grazia, V. y Furlough, E. (Eds.). The sex of things: gender and consumption in historical perspective (pp. 54-78). Berkeley: University of California Press.

Maynard, M. (2002). Blankets: the visible politics of indigenous clothing. En Parkins, W. (Ed.). Fashioning the body politic: dress, gender, citizenship (pp. 189-204). Oxford: Berg.

Meisch, L. y Rowe, A. P. (1998). Indigenous Ecuadorian costume. En Rowe, A. P. (Ed.). Costume and identity in highland Ecuador (pp. 39-49). Washington DC: The Textile Museum.

Milton, J., Orsi, R. y Harrison, N. (1986). The serpent and the robe: The pre-Colombian god-kings; The papal states. Boston: Boston Publishing.

Möntell, G. (1929). Dress and ornament in ancient Peru: archaeological and historical studies. Göteborg: Elanders Boktryckeri Aktiebolag.
Murra, J. (1962). Cloth and its functions in the Inca state. American Anthropologist, 64(4), 710-728.

Parkins, W. (2002). Introduction: (Ad)dressing citizens. En Parkins, W. (Ed.). Fashioning the body politic: dress, gender, citizenship (pp. 1-17). Oxford: Berg.

Pillsbury, J. (2002). Inca unku: strategy and design in Colonial Peru. Cleveland Studies in the History of Art, 7, 68-103.

Pillsbury, J. (2006). Inca-Colonial tunics: a case study of the Bandelier set. En Young-Sanchez, M. y Simpson, F. W. (Eds.). Andean textile traditions. Papers from the 2001 Mayer center symposium at the Denver art museum, (pp. 122-168). Denver: Denver Art Museum.

Pizarro, P. (1944) [1571]. Relación del descubrimiento y conquista de los reinos del Perú y del gobierno y orden que los naturales tenian, y tesoros que en ella se hallaron, y de las demás cosas que en él han subcedido hasta el dia de la fecha. Buenos Aires: Futuro.

Robinson, N. V. (1987). Mantones de Manila: their role in China's silk trade. Arts of Asia, 17(1), 65-75.

Romero, C. A. (1923). Festividades del tiempo heroico del Cuzco. Inca, 1, 447-454.

Rowe, A. P. (1978). Technical features of Inca tapestry tunics. Textile Museum Journal, 17, 5-28.

Rowe, J. H. (1954). El movimiento nacional Inca del siglo XVIII. Revista Universitaria, 43, 17-47.

Salomon, F. (1987). Ancestor cults and resistance to the state in Arequipa, ca. 1748-1754. En Stern, S. J. (Ed.). Resistance, rebellion, and consciousness in the Andean peasant world, $18^{\text {th }}$ to $20^{\text {th }}$ centuries (pp. 148-165). Madison: University of Wisconsin Press.

Schneider, D. (2007). La mama negra - ¿Símbolo de la multiculturalidad ecuatoriana? Indiana, 24, 157-71.

Shammas, C. (1995). Anglo-American household government in comparative perspective. The William and Mary Quarterly, 52(1), 104-44.

Stanfield-Mazzi, M. (2015). Weaving and tailoring the Andean church: textile ornaments and their makers in colonial Peru. The Americas: A Quarterly Review of Latin American History, 72(1), 77-102. 
Twinam, A. (2002). Pedro de Ayarza: the purchase of whiteness. En Andrien, K. J. (Ed.). The human tradition in colonial Latin America (pp. 194-210). Delaware: Scholarly Resources Press.

Van Vleet, K. (2005). Dancing on the borderlands: girls (re) fashioning national belonging in the Andes. En Canessa, A. (Ed.). Natives making nation: gender, indigeneity, and the state in the Andes (pp. 107-129). Tucson: University of Arizona Press.

Voss, B. L. (2008). "Poor people in silk shirts": dress and ethnogenesis in Spanish-colonial San Francisco. Journal of Social Archaeology, 8(3), 404-432.

Weismantel, M. (2001). Cholas and pishtacos: stories of race and sex in the Andes. Chicago: University of Chicago Press. 
